\title{
Effect of Plant Density and Seed Position on Mother Plant on Physiological Characteristic of Cocklebur (Xanthium strumarium) SEEDS ${ }^{1}$
}

\author{
Efeito da Densidade de Plantas e Posição das Sementes na Planta-Mãe sobre as Características \\ Fisiológicas de Sementes de Carrapicho (Xanthium strumarium)
}

FOROUGHI, A. ${ }^{2}$, GHEREKHLOO, J.2 ${ }^{2}$ and GHADERI-FAR, F. ${ }^{2}$

\begin{abstract}
Experiments were conducted in 2010 to determine the influence of plant density and seed position on the mother plant on seed physiological characteristics of cocklebur (Xanthium strumarium). Cocklebur burs were collected in fall of 2010 from Research Farm of University of Agricultural Sciences and Natural Resources of Gorgan, Iran. The experiment was established as factorial arrangement using a completely randomized design with three replications. The factors included different densities of cocklebur $\left(0,2,4,6\right.$ and 8 plant $\left.\mathrm{m}^{-2}\right)$ and the top and bottom parts of the canopy. Non dormant seeds were used for determining cardinal temperatures and tolerance to salinity and drought stresses. Base, optimum and ceiling germination temperatures were estimated between 7.09 to 12.33 , 32 to 35 and 44 to 45 respectively in different treatments. Salinity stress up to $300 \mathrm{Mm}$ and osmotic potential 8 bar inhibited the germination completely. Comparison of base temperatures and sigmoid equation coefficients showed that seeds produced in the top had higher germination than those that produced at the bottom of the mother plant. It seems plant densities through seed position on the mother plant affect seed quality. Likewise changes of light quality and quantity in shade environment increased seed dormancy in matured seeds. Shade environment affect seed germination on mother plant that increased dormancy of seeds maturing under shade be an adaptive response that reduces the probability of germination of offspring under unfavorable (shade, competitive) conditions.
\end{abstract}

Keyword: shade environment, cardinal temperature, competition, dormancy.

RESUMO - Em 2010, foram conduzidos experimentos para determinar a influência da densidade de plantas e posição das sementes na planta-mãe sobre as características fisiológicas de carrapicho (Xanthium strumarium). Espinhos de carrapicho foram coletados no outono de 2010 na Fazenda de Pesquisa da Universidade de Ciências da Agricultura e Recursos Naturais de Gorgan, Irã. O experimento foi estabelecido como um arranjo fatorial usando um delineamento inteiramente casualizado, com três repetições. Os fatores incluíram diferentes densidades de carrapicho $(0,2,4,6$ e 8 plantas $\mathrm{m}^{-2}$ ) e as partes superior e inferior da copa. Sementes não dormentes foram utilizadas para determinar as temperaturas cardeais e a tolerância à salinidade e estresse hídrico. Temperaturas de germinação base, ideal e teto foram estimadas de 7,09 a 12,33; 32 a 35; e 44 a 45 nos diferentes tratamentos. $O$ estresse de salinidade até $300 \mathrm{Mm}$ e potencial osmótico de 8 bar inibiram a completamente germinação. A comparação das temperaturas base e coeficientes da equação sigmoide mostraram que as sementes produzidas no topo possuiam maior germinação do que aquelas produzidas na base da planta-mãe. As densidades de planta através do posicionamento da semente na planta-mãe afetam a qualidade da semente. Da mesma forma, mudanças na qualidade e quantidade de luz em ambiente de sombra aumentou a dormência em sementes maduras. O ambiente de sombra afeta a germinação na planta-mãe, o que aumentou a dormência das sementes em maturação sob a sombra, uma resposta adaptativa que reduz a probabilidade de germinação de plântulas sob condições desfavoráveis (sombra, competitividade).

Palavras-chave: ambiente de sombra, temperatura cardeal, competição, dormência.

Recebido para publicação em 27.7.2013 e aprovado em 8.9.2013.

University of Agricultural Sciences and Natural Resources, Gorgan, Irã, <abbasfrooghi@yahoo.com>.

Planta Daninha, Viçosa-MG, v. 32, n. 1, p. 61-68, 2014 


\section{INTRODUCTION}

Environmental factors such as temperature, light, $\mathrm{pH}$, and soil moisture are known to affect seed germination (Ikeda et al., 2008; Rizzardi et al., 2009).

The differences in environment experienced by the mother plant during seed maturation can cause differences in weed seed germination within a population (Kigel et al., 1977; Baskin \& Baskin, 1998; Kegode \& Pearce, 1998; Munir et al., 2001; Luzuriaga et al., 2006). The seed germination response of wild mustard (Sinapsis arvensis) varied with nitrogen and water availability to the mother plants (Luzuriaga et al., 2006). Kegode $\&$ Pearce (1998) found that field-raised giant foxtail (Setaria faberi) and shattercane [Sorghum bicolor] seeds had higher germination than greenhouse-raised seeds due to higher temperature fluctuations experienced by the mother pants grown in the field.

Redroot pigweed (Amaranthus retroflexus) seed germination was affected by maternal photoperiod and temperature environments (Kigel et al., 1977). Maternal light environment effects on seed germination have been documented in several weed species (Kigel et al., 1977; Bello et al., 1995; Brainard et al., 2005). A reduction in maternal light environment (photosynthetic active radiation [PAR]) increased velvetleaf (Abutilon theophrasti.) seed germination (Bello et al., 1995).

In redroot pigweed, $73 \%$ shading of the mother plant resulted in reduced seed dormancy under short day (8-h light) and increased seed dormancy under long day (16-h light) conditions (Kigel et al., 1977). Brainard et al. (2005) reported a 40 to $50 \%$ decrease in germination of Powell amaranth (Amaranthus powelli) seeds maturing under canopy shade (up to $91 \%$ ) compared with those matured under full sunlight. Seeds maturing in separate locations within an inflorescence or in inflorescences born at different locations on the mother plant can exhibit variation in germination (Hendrix, 1984; Gray \& Steckel, 1985; Baskin \& Baskin, 1998).

A seed positioning effect on germination was evident in wild parsnip (Pastinaca sativa) seeds originating from primary, secondary, and tertiary umbels (Hendrix, 1984; Gray \& Steckel, 1985). Based on the phenological order of umbel development, seed ripening and maturation in those umbels occurred at different times, exposing the seeds to varying environmental conditions and thus, causing differences in germination of seeds produced by the plant (Hendrix, 1984; Gray \& Steckel, 1985).

El-Keblawy \& Al-Ansari (2000) reported that the germination response of the common purslane (Portulaca oleracea) seeds varied due to differences in time of seed maturation on the mother plant. There is no research on the effects of light availability of the mother plant on the germination of progeny seeds of Amaranthus species.

The objectives of this research on Xanthium strumarium, a member of the Asteraceae family and one of the most troublesome weeds of crops in soybean, cotton, peanut, and other summer crops (Wassom et al., 2002; Schmidt et al., 2004; Norsworthy $\&$ Oliveira, 2007) were to determine (1) if the germination of fresh viable seeds of Xanthium strumarium was influenced by shading of the mother plant and seed position on the mother plant, (2) if weed densities can affect the germination of fresh viable seeds of Xanthium strumarium.

\section{MATERIALS AND METHODS}

\section{Seed samples}

Cocklebur (Xanthium strumarium) burs were collected from the Research Farm of the Gorgan University of Agricultural Sciences and Natural Resources, Iran, during December 2010 from different weed densities of 2 , 4, 6 and 8 plants per $\mathrm{m}^{-2}$. Each plant was divided into top and bottom parts. Large seeds in each capsule with no dormancy (Buhler \& Hoffman, 1999) were used for conducting the experiments. Different treatments were selected based on the latest research in the same field on Yello Sweet Clover (Melilotus officinalis) (Ghaderi-Far et al., 2010).

\section{Cardinal temperatures}

To determine the cardinal temperatures, seed germination was tested on 3 replicates 
of 25 seeds in moist paper towels in the incubators at constant temperatures of 15 , $20,25,30,35,37,40$ and $45^{\circ} \mathrm{C}$ in darkness. Seeds were observed twice daily and considered germinated when the radical was approximately $2 \mathrm{~mm}$ long or more (GhaderiFar et al., 2010). Water was added as required. The distilled water used for replenishment of moisture was kept in an incubator to ensure a water temperature was consistent with the temperature in the incubator. Estimates of the time taken for cumulative germination to reach $50 \%$ of its maximum at each replicate (D50) were interpolated from the germination progress curve versus time. The germination rate $\left(\mathrm{R} 50 \mathrm{~h}^{-1}\right)$ was then calculated as (Soltani et al., 2002):

$$
\mathrm{R} 50=1 / \mathrm{D} 50
$$

\section{Effect of salinity}

To investigate the effect of salt stress on the germination of the collected seeds, three replicates of 25 seeds were incubated in moist paper towels with sodium chloride solutions of $0,50,75,100,150,200,250$ and $300 \mathrm{Mm}$ (Ghaderi-Far et al., 2010). Then the treated seeds were incubated at $35{ }^{\circ} \mathrm{C}$ in darkness.

\section{Effect of osmotic stress}

To evaluate the effect of osmotic stress on the germination of the collected cocklebur seeds, three replicates of 25 seeds were incubated in moist paper towels containing solutions with osmotic potentials of $0,-2$, $-4,-6$, and -8 bar, prepared by dissolving, respectively ${ }_{2} 0,0.126,0.185,0.231$ and $0.270 \mathrm{~g}$ polyethylene glycol 8000 in $\mathrm{ml}$ distilled water as described by Michel (1983). The seeds were then incubated at $35^{\circ} \mathrm{C}$ in darkness.

\section{Statistical analysis}

All experiments were conducted in a completely randomized design with factorial arrangement of treatments and with three replicates. The factors included different densities of cocklebur $\left(0,2,4,6\right.$ and 8 plant $\left.\mathrm{m}^{-2}\right)$ and two parts of top and bottom of canopy. The segmented model (Equation 2) was used to quantify the response of the germination rate to temperature and to estimate the cardinal temperatures (Soltani et al., 2006).

$$
\begin{array}{ll}
\mathrm{f}(\mathrm{T}) & =\left(T-T_{b}\right) /\left(T_{o}-T_{b}\right) \text { if } T_{b}<T<T_{o} \\
\mathrm{f}(\mathrm{T}) & =\left(T_{c}-T\right) /\left(T_{c}-T_{o}\right) \text { if } T_{o}<T<T_{c} \\
\mathrm{f}(\mathrm{T}) & =0 \quad \text { if } T \leq T_{b} \text { or } T \geq T_{c}
\end{array}
$$

where $T$ is the temperature, and $T_{b}, T_{o}$ and $T_{c}$ are the base, optimum and ceiling temperatures, respectively.

A three-parameter logistic model was fitted to the data from the salt and osmotic experiments (Equation 3).

$$
Y=\left(a /\left(1+(s / b)^{c}\right)\right) \quad \text { eq. }
$$

where $Y$ is the total germination (\%) at concentration $s, a$ is the maximum germination (\%), $b$ is the $\mathrm{NaCl}$ or osmotic potential required for $50 \%$ inhibition of the maximum germination and $c$ indicates the slope of the curve in b. The statistical analysis system (SAS) was used for analyzing data (SAS, 1989).

\section{RESULTS}

The effect of temperature on the germination rate was described by a segmented model (Figure 1). The germination rate increases from base to optimum temperature and then decreases to a ceiling temperature (Alvarado \& Bradford, 2002). The base, optimum and ceiling temperatures were estimated at 7.09 to $12.33,32$ to 35 and 44 to $45{ }^{\circ} \mathrm{C}$ in the different treatments (Table 1 ). The maximum germination occurred between 30 and $35{ }^{\circ} \mathrm{C}$ (Figure 1 and 2). A sharp decrease in germination occurred when temperature was outside of this range and germination reached a minimum at 15 and $45{ }^{\circ} \mathrm{C}$ (Figure 2). The germination of fresh and viable seeds of Xanthium strumarium was influenced by the position of seeds on the mother plant. Seeds produced at the top portion of the plant had higher germination than those produced at the bottom of the mother plant (Figure 1 and 2).

\section{Effect of salt and osmotic stress}

The germination of cocklebur seeds declined with the increase in salinity following a sigmoid trend, and was completely inhibited 

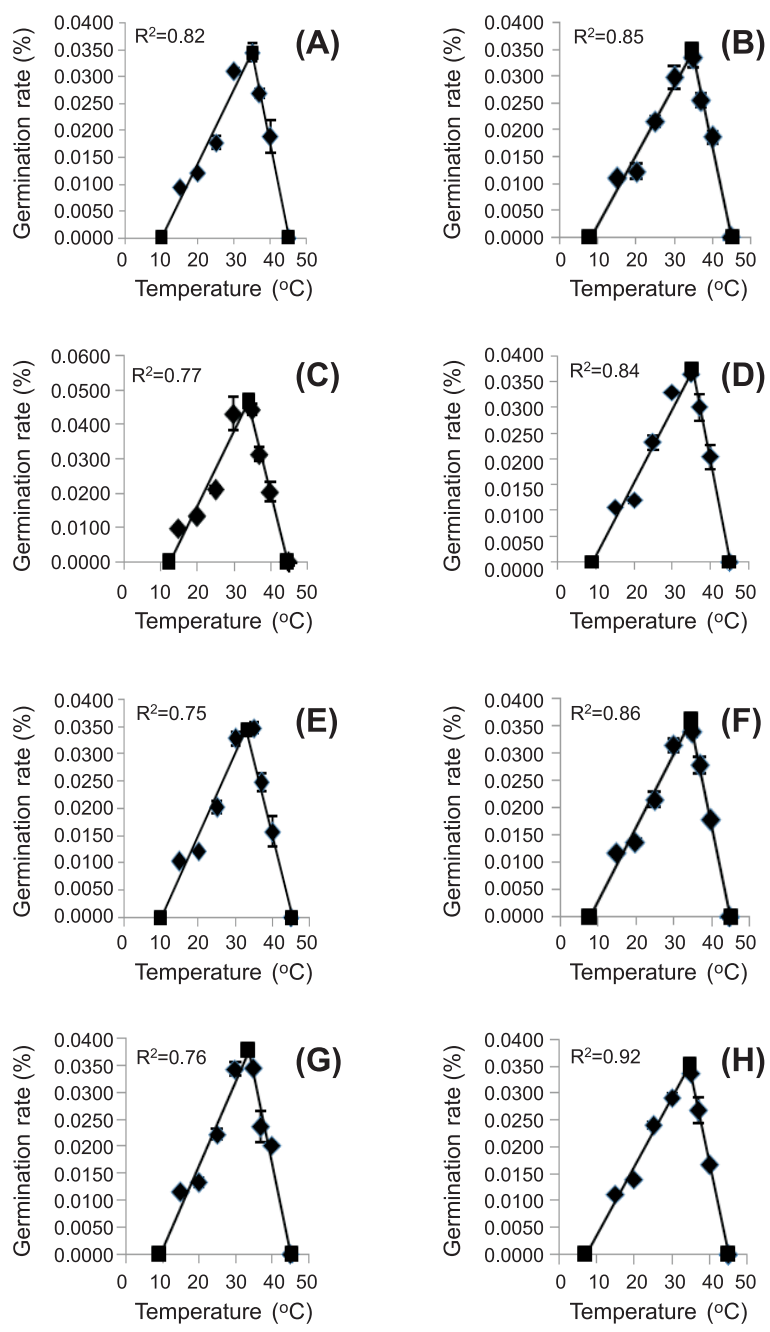

(A) 2 plant $\mathrm{m}^{-2}$, bottom of mother plant; (B) 2 plant $\mathrm{m}^{-2}$, top of mother plant; (C) 4 plant $\mathrm{m}^{-2}$, bottom of mother plant; (D) 4 plant $\mathrm{m}^{-2}$, top of mother plant; (E) 6 plant $\mathrm{m}^{-2}$, bottom of mother plant; (F) 6 plant $\mathrm{m}^{-2}$, top of mother plant; (G) 8 plant $\mathrm{m}^{-2}$, bottom of mother plant; $(\mathrm{H}) 8$ plant $\mathrm{m}^{-2}$, top of mother plant.

Figure 1 - Effect of temperature on the germination rate of cocklebur seeds collected from different densities and different heights of canopy.

at $300 \mathrm{Mm}$ salinity (Figure 3). The comparison of concentrations required for $50 \%$ inhibition (b) in different treatments showed that more concentration of $\mathrm{NaCl}$ was necessary for seeds that matured at the top of the canopy (Table 2). The seed germination of $X$. strumarium was also obviously affected by increasing water stress. The germination percentage decreased with the increase in osmotic potential and was completely inhibited in osmotic potential of -8 bar (Figures 3,4$)$. With regard to Tables 2
Table 1 - Estimated cardinal temperatures of cocklebur seeds collected from different densities and different heights of canopy

\begin{tabular}{|c|c|r|c|}
\hline $\begin{array}{c}\text { Model } \\
\text { coefficients } \\
\text { treatments }\end{array}$ & $\mathrm{T}_{\mathrm{b}}$ & \multicolumn{1}{|c|}{$\mathrm{T}_{\mathrm{o}}$} & $\mathrm{T}_{\mathrm{c}}$ \\
\hline $\mathrm{A}$ & $9.91 \pm 1.48$ & $35.01 \pm 0.56$ & $45.14 \pm 0.55$ \\
\hline $\mathrm{B}$ & $7.81 \pm 1.54$ & $34.6 \pm 0.44$ & $45.18 \pm 0.4$ \\
\hline $\mathrm{C}$ & $12.33 \pm 1.46$ & $34 \pm 0.67$ & $44.84 \pm 0.63$ \\
\hline $\mathrm{D}$ & $9.3 \pm 1.36$ & $35.24 \pm 0.46$ & $45.1 \pm 0.46$ \\
\hline $\mathrm{E}$ & $10.02 \pm 1.52$ & $32.84 \pm 0.63$ & $45.31 \pm 0.64$ \\
\hline $\mathrm{F}$ & $7.94 \pm 1.3$ & $34.55 \pm 0.38$ & $45.07 \pm 0.34$ \\
\hline $\mathrm{G}$ & $9.33 \pm 1.6$ & $33.68 \pm 0.57$ & $45.27 \pm 0.56$ \\
\hline $\mathrm{H}$ & $7.09 \pm 1.34$ & $34.57 \pm 0.33$ & $44.98 \pm 0.29$ \\
\hline
\end{tabular}

$\mathrm{T}_{\mathrm{b}}$ : base temperature, $\mathrm{T}_{0}$ : optimum temperature, $\mathrm{T}_{\mathrm{c}}$ : ceiling temperature.

and 3 it could be concluded that the seeds matured at the top of the canopy had a_higher germination rate ( $a$ parameter) than those matured at the bottom of the canopy.

\section{DISCUSSION}

The increased germination rate and percentage of seeds located at the top of the mother plant confirmed the importance of seed positioning on the mother plant for the germination of cocklebur seeds (Figure 1 and 2). The environmental differences experienced by the mother plant during seed maturation can cause differences in the seed germination of weeds within a population (Munir et al., 2001; Luzuriaga et al., 2006). Brainard et al. (2005) reported a 40 to $50 \%$ decrease in germination of Powel amaranth (Amaranthus powellis) seeds maturing under canopy shade (up to $91 \%$ ) compared with those matured under full sunlight. Seed maturing in separate locations within an inflorescence or in inflorescences borne at different locations on the mother plant can exhibit variations in germination (Baskin \& Baskin, 1998).

The differences in the time of seed maturation at the top compared to the bottom location of the mother plant might contribute to the variation in seed germination. The influence of physiological age or time of seed maturation on the mother plant on the_germination of fresh seeds has been 

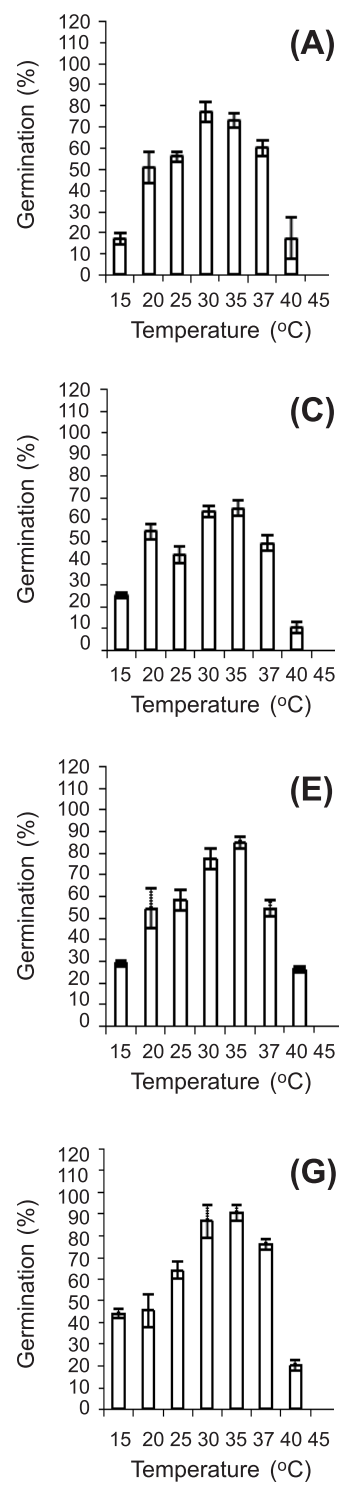
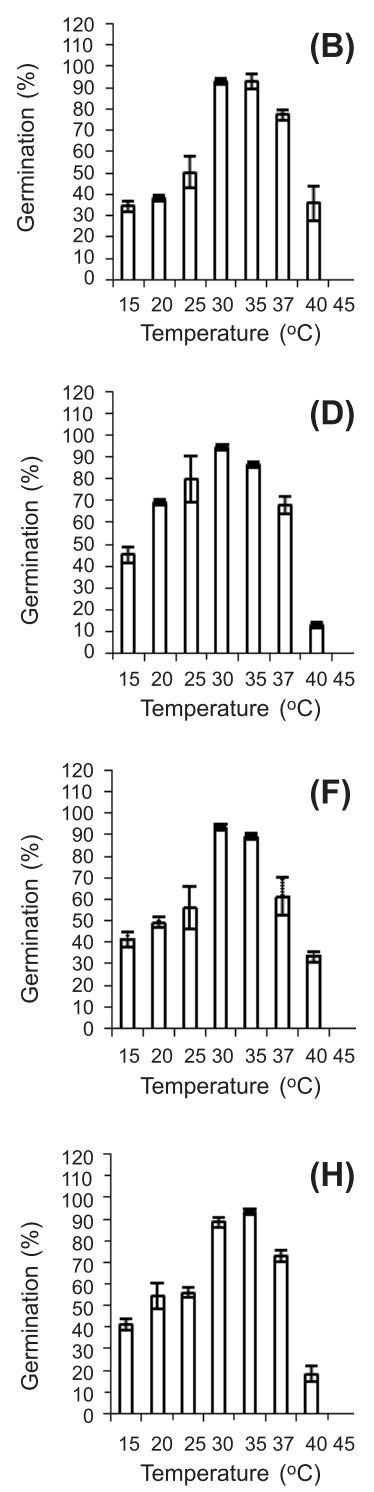

(A) 2 plant $\mathrm{m}^{-2}$, bottom of mother plant; (B) 2 plant $\mathrm{m}^{-2}$, top of mother plant; (C) 4 plant $\mathrm{m}^{-2}$, bottom of mother plant; (D) 4 plant $\mathrm{m}^{-2}$, top of mother plant; (E) 6 plant $\mathrm{m}^{-2}$, bottom of mother plant; (F) 6 plant $\mathrm{m}^{-2}$, top of mother plant; (G) 8 plant $\mathrm{m}^{-2}$, bottom of mother plant; (H) 8 plant.m ${ }^{-2}$, top of mother plant.

Figure 2 - Effect of temperature on the germination of cocklebur seeds collected from different densities and different heights of canopy.

previously documented in other species (Baskin \& Baskin, 1998). El-Keblawy \& Al-Ansari (2000) reported that the germination response of common purslane (Portulaca oleracea) seeds varied due to differences in time of seed maturation on the mother plant.
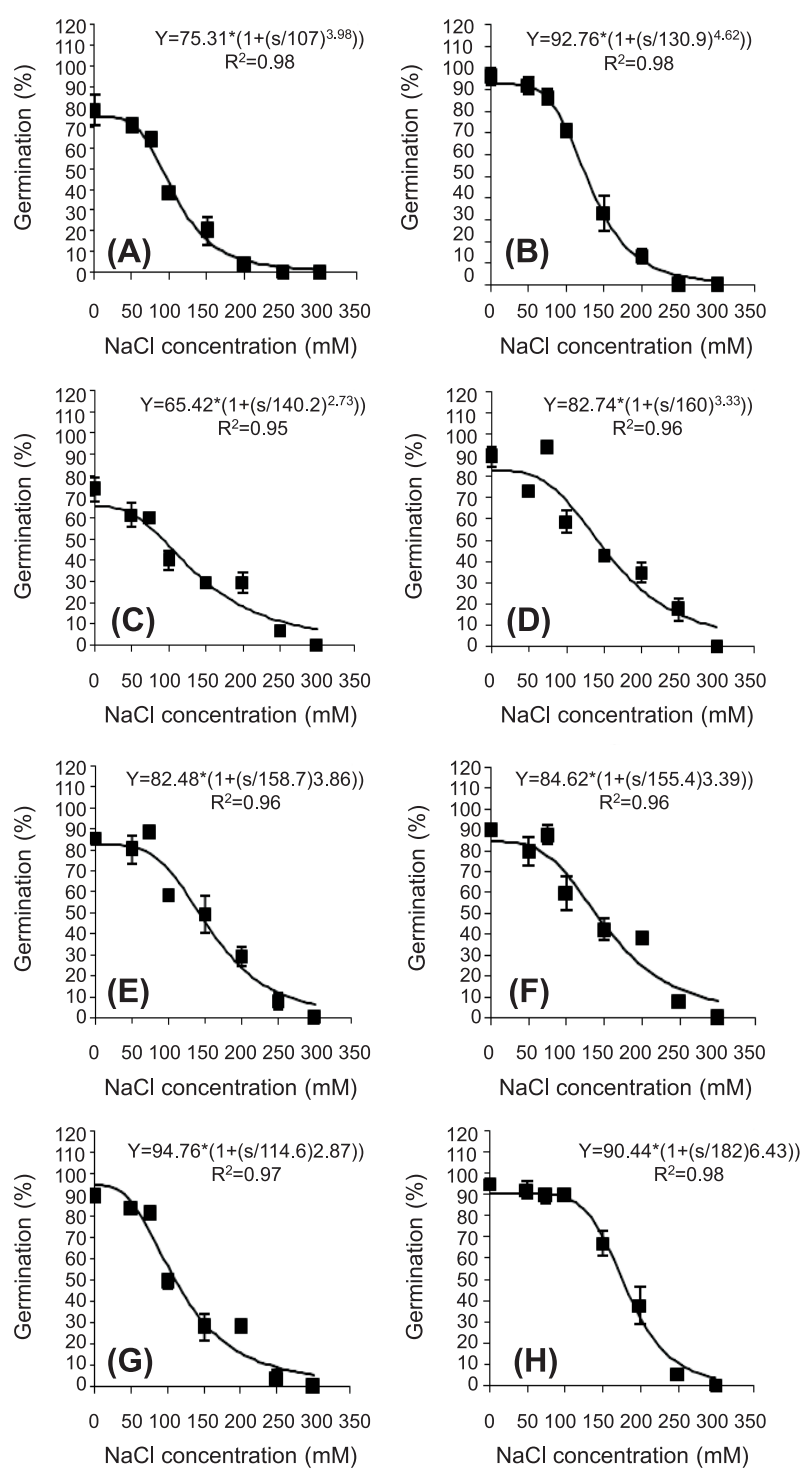

(A) 2 plant $\mathrm{m}^{-2}$, bottom of mother plant; (B) 2 plant $\mathrm{m}^{-2}$, top of mother plant; (C) 4 plant $\mathrm{m}^{-2}$, bottom of mother plant; (D) 4 plant $\mathrm{m}^{-2}$, top of mother plant; (E) 6 plant $\mathrm{m}^{-2}$, bottom of mother plant; (F) 6 plant $\mathrm{m}^{-2}$, top of mother plant; (G) 8 plant $\mathrm{m}^{-2}$, bottom of mother plant; (H) 8 plant $\mathrm{m}^{-2}$, top of mother plant.

Figure 3 - Effect of $\mathrm{NaCl}$ concentration on the germination of cocklebur seeds in different densities and heights of canopy.

Under canopy shade, both the R-FR ration and irradiance decline, and thus, the impact of shade on the timing of flowering is difficult to predict. In most cases, competition results in either no change or in a delay in the onset of reproduction (Weiner, 1988). Endogenous 
Table 2 - Eestimated sigmoid model coefficient of salinity stress in the germination of cocklebur seeds at optimum temperature

\begin{tabular}{|c|c|c|c|}
\hline $\begin{array}{c}\text { Model } \\
\text { coefficients } \\
\text { treatments }\end{array}$ & $\mathrm{a}$ & $\mathrm{b}$ & $\mathrm{c}$ \\
\hline $\mathrm{A}$ & $75.31 \pm 4.57$ & $107 \pm 5.69$ & $3.98 \pm 0.56$ \\
\hline $\mathrm{B}$ & $92.76 \pm 3.69$ & $130.9 \pm 5.16$ & $4.62 \pm 0.58$ \\
\hline $\mathrm{C}$ & $65.42 \pm 7.78$ & $140.2 \pm 19.8$ & $2.73 \pm 0.70$ \\
\hline $\mathrm{D}$ & $82.74 \pm 6.97$ & $160 \pm 15.62$ & $3.33 \pm 0.83$ \\
\hline $\mathrm{E}$ & $82.48 \pm 5.75$ & $158.7 \pm 12.31$ & $3.86 \pm 0.88$ \\
\hline $\mathrm{F}$ & $84.62 \pm 7.26$ & $155.4 \pm 15.28$ & $3.39 \pm 0.84$ \\
\hline $\mathrm{G}$ & $94.76 \pm 9.83$ & $114.6 \pm 12.7$ & $2.87 \pm 0.53$ \\
\hline $\mathrm{H}$ & $90.44 \pm 2.81$ & $182 \pm 5.37$ & $6.43 \pm 0.97$ \\
\hline
\end{tabular}

a: maximum germination (\%), b: $\mathrm{NaCl}$ required for $50 \%$ inhibition of the maximum germination, c: slope of the curve in b.

levels of ABA and GA in seeds, or changes in the_sensitivity of seeds to these hormones, are affected by environmental conditions during seed development (Walker-Simmons, 1987; Romagosa et al., 2001). Northworthy et al. (2010) reported that increasing the shading from 0 to $87 \%$ decreased germination of fresh, viable seeds in darkness from 25 to $12 \%$, and the content of Abscisic acid (ABA) seeds from plants in $0 \%$ shade increased $13.3 \mathrm{ng} \mathrm{g}^{-1}$ dry seed to $19.1 \mathrm{ng} \mathrm{g}^{-1}$ dry seed with $87 \%$ shade. Seeds that matured at the top and middle third of the mother plant had 67 to $78 \%$ greater germination than those that matured at the bottom third of the mother plant. Brainard et al. (2005) reported that the germination percentage of viable seeds was 40 to $50 \%$ lower in seeds maturing on plants grown under competition, when compared to plants without competition.

To summarize, shading of the mother plant reduced the germination of fresh, viable seeds of Xanthium strumarium. Seeds that matured at the bottom half on the plant showed lower germination than seeds from the top locations on the mother plant. This research would aid population dynamics models and help understand the contribution of the mother plant to the variation in seed germination. Future research is needed to investigate the effects of changes in the maternal environment such as light quality, photoperiod, temperature, and nutrient availability on the germination of freshly matured Xanthium strumarium seeds. Research is also needed to determine if
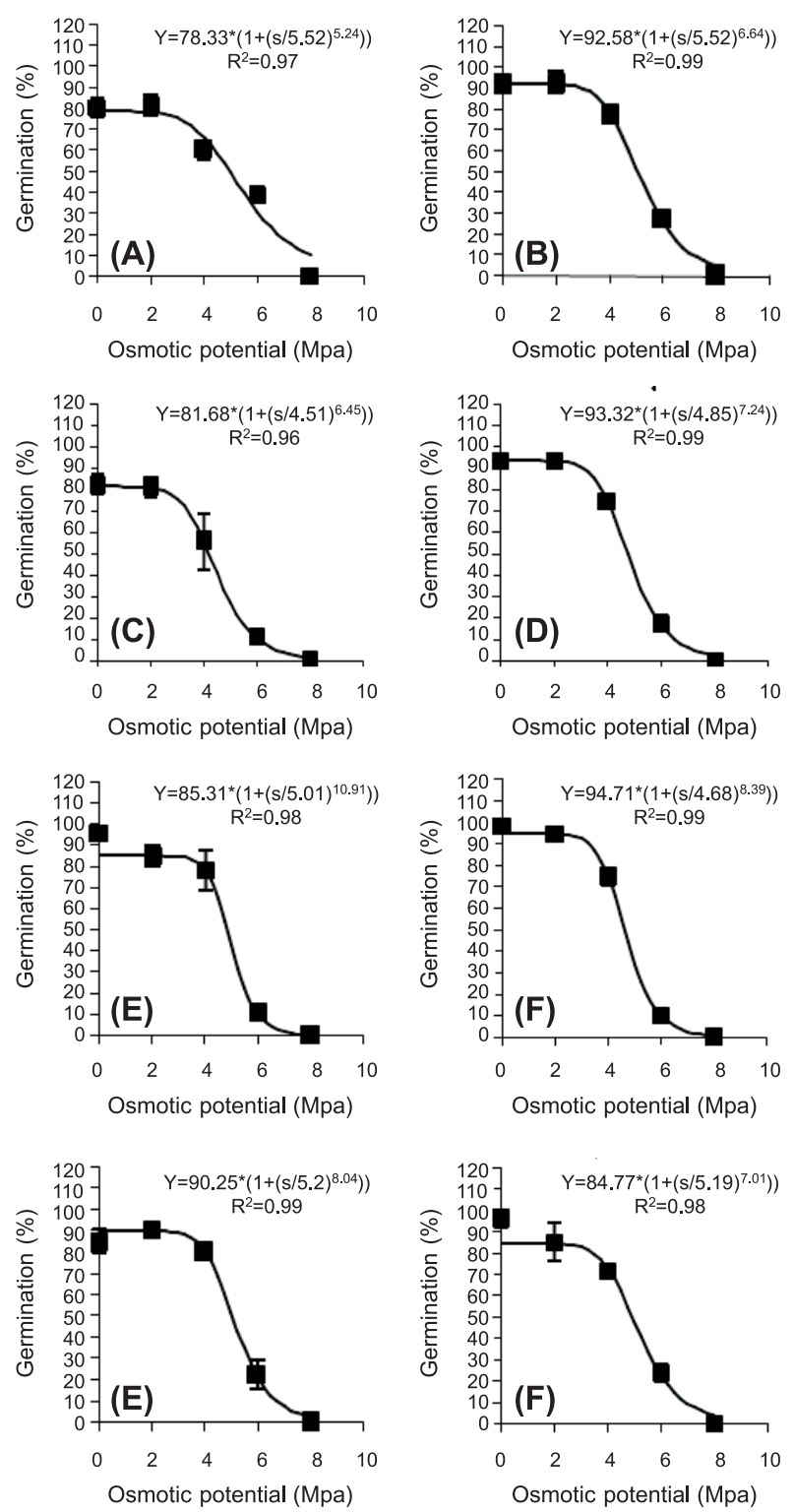

(A) 2 plant $\mathrm{m}^{-2}$, bottom of mother plant; (B) 2 plant $\mathrm{m}^{-2}$, top of mother plant; (C) 4 plant $\mathrm{m}^{-2}$, bottom of mother plant; (D) 4 plant $\mathrm{m}^{-2}$, top of mother plant; (E) 6 plant $\mathrm{m}^{-2}$, bottom of mother plant; (F) 6 plant $\mathrm{m}^{-2}$, top of mother plant; (G) 8 plant $\mathrm{m}^{-}$ 2, bottom of mother plant; (H) 8 plant.m ${ }^{-2}$, top of mother plant.

Figure 4 - Effect of osmotic potential on the germination of cocklebur seeds collected from different densities and different heights of canopy.

differences in time of seed maturation, seed coat thickness, structure, and permeability as functions of the maternal environment could explain variations in the germination of Xanthium strumarium seeds-prior to afterripening. 
Table 3 - Estimated sigmoid model coefficient fitted to the germination of cocklebur seeds collected from different densities and different heights of canopy in different drought stress levels

\begin{tabular}{|c|c|r|r|}
\hline $\begin{array}{c}\text { Model } \\
\text { coefficients } \\
\text { treatments }\end{array}$ & $\mathrm{a}$ & \multicolumn{1}{c|}{$\mathrm{b}$} & $\mathrm{c}$ \\
\hline $\mathrm{A}$ & $78.33 \pm 6.21$ & $5.52 \pm 0.37$ & $5.24 \pm 1.48$ \\
\hline $\mathrm{B}$ & $92.58 \pm 3.26$ & $5.2 \pm 0.14$ & $6.64 \pm 0.84$ \\
\hline $\mathrm{C}$ & $81.68 \pm 6.89$ & $4.51 \pm 0.27$ & $6.45 \pm 1.89$ \\
\hline $\mathrm{D}$ & $93.32 \pm 2.85$ & $4.85 \pm 0.11$ & $7.24 \pm 0.72$ \\
\hline $\mathrm{E}$ & $85.31 \pm 5.22$ & $5.01 \pm 0.28$ & $10.91 \pm 3.07$ \\
\hline $\mathrm{F}$ & $94.71 \pm 2.48$ & $4.68 \pm 0.09$ & $8.39 \pm 0.78$ \\
\hline $\mathrm{G}$ & $90.25 \pm 3.99$ & $5.2 \pm 0.18$ & $8.04 \pm 1.48$ \\
\hline $\mathrm{H}$ & $84.77 \pm 4.92$ & $5.19 \pm 0.24$ & $7.01 \pm 1.51$ \\
\hline
\end{tabular}

a: maximum germination (\%), b: osmotic potential required for $50 \%$ inhibition of the maximum germination, c: slope of the curve in b.

\section{LITERATURE CITED}

ALVARADO, V.; BRADFORD, K. J. A hydrothermal time model explains the cardinal temperatures for seed germination. Plant Cell. Environ., v. 25, n. 8, p. 1061-1069, 2002.

BASKIN, C. C.; BASKIN, J. M. Seeds, ecology, biogeography, and evolution of dormancy, and germination. San Diego: Academic, 1998. p. 230-235.

BELLO, I. A.; OWEN, M. D. K.; HATTERMANVALENTI, H. M. Effect of shading on velvetleaf (Abutilon theophrasti) growth, seed production, and dormancy. Weed Technol., v. 9, n. 3, p. 452-455, 1995.

BRAINARD, D. C.; BELLINDER, R. R.; DITOMMASO, A. Effects of canopy shade on the morphology, phenology, and seed characteristics of Powell amaranth (Amaranthus powelli). Weed Sci., v. 53, n. 2, p. 175-186, 2005.

BUHLER, D. D.; HOFFMAN, M. L. Andersen's guid to practical methods of propagating weeds and other plants. Lawrence: Weed Science Society of America/Allen Press, 1999. 248 p.

EL-KEBLAWY, A.; AL-ANSARI, F. Effects of site of origin, time of seed maturation, and seed age on germination behavior of Portulaca oleracea from the old and new worlds. Can. J. Bot., v. 78, n. 3, p. 279-287, 2000.

GHADERI-FAR, F.; GHEREKHLOO, J.; ALIMAGHAM, $M$. Influence of environmental factors on seed germination and seeding emergence of yello sweet clover (Melilotus officinalis). Planta Daninha, v. 28, n. 3, p. 463-469, 2010.
GRAY, D.; STECKEL, J. R. A. Parsnip (Pastinaca sativa) seed production: effects of seed crop plant density, seed position on the mother plant, harvest date and method, and seed grading on embryo and seed size and seedling performance. Ann. Appl. Biol., v. 107, n. 3, p. 559-570, 1985.

HENDRIX, S. D. Variation in seed weight and its effects on germination in Pastinaca sativa L. (Umbelliferae). Am. J. Bot., v. 71, n. 6, p. 795-802, 1984.

IKEDA, F. S. et al. Light and KNO3 on Tridax procumbens seed germination at constant and alternating temperatures. Planta Daninha, v. 26, n. 4, p. 751-756, 2008.

KEGODE, G. O.; PEARCE, R. B. Influence of environment during mother plant growth on dormancy of shattercane (Sorghum bicolor) and giant foxtail (Setaria faberi) seed. Weed Sci., v. 46, n. 3, p. 322-329, 1998.

KIGEL, J.; OFIR, M.; KOLLER, D. Control of the germination responses of Amaranthus retroflexus L. seeds by the parental photothermal environment. J. Exper. Bot., v. 28, n. 5, p. 1125-1136, 1977.

LUZURIAGA, A. L.; ESCUDERO, A.; PEREZ-GARCIA, F. Environmental maternal effects on seed morphology and germination in Sinapis arvensis (Cruciferae). Weed Res., v. 46, n. 2, p. 163-174, 2006.

MICHEL, B. E. Evaluation of water potential of solution of polyethylene glycol 8000 both in absence and presence of other solutes. Plant Physiol., v. 72, n. 1, p. 66-70, 1983.

MORGAN, D. C.; SMITH, H. Linear relationship between phytochrome photoequilibrium and growth in plants under simulated natural radiation. Nature, v. 262, n. 10, p. 210-212, 1976.

MUNIR, J. et al. The effect of maternal photoperiod on seasonal dormancy in Arabidopsis thaliana (Brassicaceae). Am. J. Bot., v. 88, n. 7, p. 1240-1249, 2001.

NORSWORTHY, J. K.; OLIVEIRA, M. J. Light and temperature requirements for common cocklebur (Xanthium strumarium) germination during after-ripening under field conditions. Weed Sci., v. 55, n. 3, p. 227-234, 2007.

PRASHANT, J. et al. Shade and plant location effects on germination and hormone content of palmer amaranth (Amaranthus palmeri) seed. Weed Sci., v. 58, n. 1, p. 16-21, 2010.

RIZZARDI, M. A. et al. Effect of cardinal temperature and water potential on morning glory (Ipomoea triloba) seed germination. Planta Daninha, v. 27, n. 1, p. 13-21, 2009.

ROMAGOSA, I. et al. Dormancy, ABA content and sensitivity of a barley mutant to ABA application during seed development and after ripening. J. Exper. Bot., v. 52, n. 360, p. 1499-1506, 2001.

Planta Daninha, Viçosa-MG, v. 32, n. 1, p. 61-68, 2014 
SAS Institute. User’s guide. Version 6. 4.ed. Cary: 1989. 943 p.

SCHMIDT, L. A.; TALBERT, R. E.; MC CLELLAND, M. Management of acetolactate synthase (ALS) - resistant common cocklebur (Xanthium strumarium) in soybean. Weed Technol., v. 18, n. 3, p. 665-674, 2004.

SOLTANI, A. et al. Germination seed reserve utilization and growth of chickpea as affected by salinity and seed size.

Seed Sci.Technol., v. 30, n. 1, p. 51-60, 2002.

SOLTANI, A. et al. Modeling seedling emergence in chickpea as affected by temperature and sowing depth. Agric. For.

Meteriol., v. 138, n. 1/4, p. 156-167, 2006.
WALKER-SIMMONS, M. ABA levels and sensitivity in developing wheat embryos of sprouting resistant and susceptible cultivars. Plant Physiol., v. 84, n. 1, p. 61-66, 1987.

WASSOM, J. J.; TRANEL, P. J.; WAX, L. M. Variation among U.S. accessions of common cocklebur

(Xanthium strumarium). Weed Technol., v. 16, n. 1, p. 171-179, 2002.

WEINER, J. The influence of competition on plant reproduction. In: DOUST, J. L.; DOUST, L. L. (eds.). Plant reproductive ecology: patterns and strategies. New York: Oxford University Press, 1988. p. 228-245. 